\title{
Horizontal arrangements: strategy for reducing the asymmetry information for dairy farmers in Paraná, Brazil
}

\author{
Arranjos horizontais: estratégia para redução da assimetria de \\ informações para produtores de leite no Paraná, Brasil \\ Marcel Moreira de Brito ${ }^{\mathrm{I}}$ Ferenc Istvan Bánkuti ${ }^{\mathrm{I}^{*}}$ Sandra Mara Schiavi Bánkuti ${ }^{\mathrm{II}}$ \\ Maria Clara Melo FerreiraI Júlio César Damasceno ${ }^{I I}$ \\ Geraldo Tadeu dos Santos ${ }^{\text {II }}$ Maximiliane Alavarse Zambom ${ }^{\mathrm{I}}$
}

ABSTRACT

An empirical investigation was conducted to study whether dairy farmers involved in horizontal arrangements (HA) have lower information asymmetry than those who do not participate in HA. Our assumption is that greater access to information results in fewer risky decisions in production systems. One hundred and twenty semi-structured questionnaires were applied to dairy farmers located in four different geographical regions in Paraná State, Brazil. Exploratory factor analysis was used to define factors related to information asymmetry in dairy agribusiness system (DAS) and four factors were defined. In a second step, the 120 dairy farmers were split into two groups: the first one involved in $H A$ and the second one not involved in $H A$. Mean test (t-student) were performed to compare these groups between factors. Significant differences $(P<0.05)$ were observed for factors related to transaction information and for general market information, and dairy farmers participating in HA achieved the greatest values. Finally, it can be concluded that dairy farmers who participate in HA have higher access to information, which can create an environment with lower information asymmetry and, consequently, be subject to lower risks than dairy farmers who do not participate in $H A$.

Key words: business networking, cooperation, dairy agribusiness system.

RESUMO

$O$ objetivo definido neste trabalho foi verificar se produtores de leite que participam de arranjos horizontais (AH) possuem menor assimetria de informações, frente àqueles que não participam desses arranjos. Parte-se do pressuposto de que o maior acesso à informação resulta em menor risco para o produtor rural. Foram aplicados 120 questionários semiestruturados junto a produtores rurais de leite, localizados em quatro macrorregiões do Estado do Paraná. Foi realizada a análise fatorial exploratória
(AFE) para definição de fatores relacionados à assimetria de informação em Sistemas Produtivos Leiteiros (SPL's). Os 120 produtores entrevistados foram divididos em dois grupos: aqueles que participavam de arranjos horizontais (AH) e aqueles que não participavam. Esses grupos foram confrontados com os fatores gerados na análise anterior. Foi encontrada diferença significativa $(P<0,05)$ para os fatores "Informações relacionadas às transações" e "Informações globais para a atividade", sendo que produtores de leite que participavam de arranjos horizontais obtiveram melhores resultados. Por fim, conclui-se que produtores que participam de AH têm mais acesso à informação, o que pode criar um ambiente de menor assimetria de informações $e$ consequentemente de menor risco, comparativamente a produtores que não participam de $A H$.

Palavras-chave: cooperação, redes de negócios, sistema agroindustrial do leite.

\section{INTRODUCTION}

Brazil is among the six largest producers of milk in the world. In 2013, Brazil produced 32.4 billion liters of milk, with nearly 20 million cows in milk, according to the United States Department of Agriculture(USDA, 2014). Paraná state is a traditional dairy producer and has undergone profound changes since the 90s, especially from the expansion of the frontiers of production and the process of detachment of dairy farming to the Midwest, as related by JANK et al. (1999). Considering data reported by the Brazilian Institute of Geography and Statistics (IBGE), there is a resumption of dairy activity in

\footnotetext{
${ }^{I}$ Centro de Ciências Agrárias (CCA), Universidade Estadual do Oeste do Paraná (UNIOESTE), Marechal Cândido Rondon, PR, Brasil. IIPrograma de Pós-graduação em Zootecnia, Departamento de Zootecnia, Centro de Ciências Agrárias (CCA), Universidade Estadual de Maringá (UEM), Avenida Colombo, 5790, 87020-900, Maringá, PR, Brasil. E-mail: ferencistvan@gmail.com. "Corresponding author. IIIPrograma de Pós-graduação em Administração, Departamento de Administração, UEM, Maringá, PR, Brasil.
} 
the State, with an increase of $40.3 \%$ between 2008 and 2012. Moreover, the value of milk production in Paraná, in nominal terms, grew $102 \%$ during the same period (IBGE, 2014).

Given this scenario, the importance and growth that dairy agribusiness system (DAS) achieved in recent years is evident. However, DAS is still undergoing an economic and productive process, due to institutional and market changes that began in the 90s. The relation of purchase and sale (transactions) between dairy farmers and industry was no longer local and regulated (MAGALHÃES, 2007), to be defined mainly by criteria of physicochemical milk quality and by milk volume marketed. Moreover, given the method as those transactions were formatted, a space was opened for opportunistic behavior, mainly due to the information asymmetry about the characteristics of transactions. Supported by theories of new institutional economics (NIE) and transaction cost economics (TCE), and considering information asymmetry, every transaction involves some risk (WILLIAMSON, 1985).

Asymmetries in transactions represent a major obstacle in agribusiness systems. CARVALHO \& BARCELLOS (2013) emphasize that prices paid to dairy farmers are not consistent with the information received. According to these authors, there is great information asymmetry in transactions between dairy farmers and industry. According to NOGUEIRA (2003), the exchange of information between agents is a cooperative attitude that helps to stabilize the production system, reducing the risk of opportunistic behavior. FERNANDEZ-STARK et al. (2012) related that overcoming barriers for low and medium-income farmers involves the increased access to information.

For CARVALHO \& BARCELLOS (2013), farmer's organizations are important to minimize information and power asymmetry in transactions with buyers, given that industry may omit information concerning the composition of price to be paid for dairy farmers. Complementarily, ZYLBERSZTAJN $(1995 ; 2009)$ considered that HA promote greater information exchange between agents, which are in the same sector or not, making them more competitive.

Considering those conditions, the construction of vertical and horizontal organizational arrangements in rural production, especially for low-income dairy farmers, may represent an important strategy for supporting dairy business (MAGALHÃES, 2007). In this paper, vertical arrangements are defined as economic or social relations between agents of different levels of a supply chain, such as suppliers and buyers; while horizontal arrangements (HA) are defined as economic or social relations among actors of the same level of a supply chain, such as a group of farmers (BAUM \& INGRAM, 2002). According to FERNANDEZSTARK et al. (2012), collaborative networks between low-income farmers show essential mechanisms to enable information dissemination among peers, emphasizing the importance of HA for access to critical resources, reducing costs by scale economies, economies coordination in network, and pressures to avoid the exercise of power and opportunism in contractual relationships along the chain.

Thus, our assumption is that greater access to information results in fewer risky decisions in production systems, given the lower information asymmetry. Therefore, the hypothesis defined in this paper is that dairy farmers who participate in HA are inserted in an environment of lower information asymmetry, compared to those who do not participate in such arrangements. From this context, the objective defined in this research was to verify whether dairy farmers involved in the HA have lower information asymmetry compared to those who do not participate in these arrangements.

\section{MATERIAL AND METHODS}

This quantitative study was developed from primary data collected with dairy farmers in Paraná, Brazil. We administered questionnaires to 120 dairy farmers from March 2012 to February 2013, in four geographical regions in Paraná: Central North, Western Center, West and Southwest. The categorization of these regions was determined by milk production in the State, as well as the heterogeneity of production systems, which reflects the milk production in the State.

According to the agriculture Brazilian Census of 2006, 7100 rural farms were engaged in milk production in Paraná, being 3322 localized in the regions studied ( $47 \%$ of total). According to the same source, the four regions concentrated almost $50 \%$ of family-based farms in milk production in the state, being 736 units in central north, 702 in the west, 679 in the southwestern and 307 in the western center (IBGE, 2006). In 2013, the four regions produced together about 2.5 billion liters of milk, which corresponded to $58 \%$ of total production and $56 \%$ of value of milk production in Paraná (IBGE, 2014).

As for the sample, farmers were determined randomly based upon a contact list obtained from the city hall and Emater (Paraná Institute of Technical 
Assistance and Rural Extension). Interviews were conducted in loco, most of them during meetings convened by the research group. Collected empirical data were statistically analyzed using the statistical package for social sciences - SPSS version 18. In the first step of multivariate analysis, a set of 13 variables (Table 1) was selected to represent transaction aspects between dairy farmers and industry, access to information related to technical and management capability, general market information, technology, and institutional aspects. Variables were defined supported by new institutional economics (NIE) and its microanalytical approach of transaction cost economics (TCE), focusing on the consideration of information asymmetry (WILLIAMSON, 1985; NORTH 1990; STIGLITZ, 2002). Variables were previously tested through the conduction of a pilot questionnaire to 40 farmers.

Exploratory factor analysis (EFA) was conducted with those 13 variables. The extraction method defined was the common factors analysis with varimax rotation type, standardization of kaiser meyer olkin (KMO), and the bartlett test of sphericity (LEBART, 2000; SMITH et al., 2002; BARROSO \& ARTES, 2003). Variables with low and medium load factor (less than $|0.5|$ ) were removed (FÁVERO et al., 2009). To select the number of factors, it was used the kaiser criterion, which is based on the number of eigenvalues greater than 1.0, as suggested by HAIR et al. (1998) and FÁVERO et al. (2009).
Dairy farmers were split into two groups, those who participate in HA and those who do not participate in such arrangements. Empirically, it was considered the participation in HA as any form of collective action, such as cooperatives, associations, labor unions and buying groups. These two groups were compared with each other, considering factors previously generated by exploratory factorial analyses. To verify the equality between groups, it was used the student $t$ test, considering a level of significance of $5 \%$.

\section{RESULTS AND DISCUSSION}

Of the assessed production systems, the average area of farms was of 15.9ha, and the average number of cows in milk was 18. As for the breed, animals were predominantly crossbred, representing $59.1 \%$ of the total dairy cattle. The average production of milk in dairy production systems analyzed was 236.3 liters of milk day ${ }^{-1}$, with an average yield of $13.6 \mathrm{~kg}$ of milk cow ${ }^{-1}$ day $^{-1}$. Regarding the decisionmaking farmers, the average age was 46 years old, with an average of 17 years of experience in the dairy business. In addition, only $10 \%$ of dairy farmers had no formal education; $35 \%$ of farmers studied until middle school and $55 \%$ attended all or part of high school. Thus, in general, they are small-scale farmers, with a quite large experience in milk activity, not so young and with a reasonable level of education.

\begin{tabular}{|c|c|c|c|c|}
\hline & $\begin{array}{c}\text { F1 } \\
\text { Transaction } \\
\text { information }\end{array}$ & $\begin{array}{c}\text { F2 } \\
\text { Product } \\
\text { characteristics } \\
\text { information }\end{array}$ & $\begin{array}{c}\text { F3 } \\
\text { Technical and } \\
\text { productive } \\
\text { information }\end{array}$ & $\begin{array}{c}\text { F4 } \\
\text { General market } \\
\text { information }\end{array}$ \\
\hline Know the average of SCC in the milk produced & & 0.866 & & \\
\hline Know the average of TBC in the milk produced & & 0.836 & & \\
\hline Know the average of crude protein in the milk produced & & 0.780 & & \\
\hline Know the average of fat in the milk produced & & 0.616 & & \\
\hline Technical assistance for the farm & & & 0.840 & \\
\hline Courses for capacitation in the dairy activity & & & 0.911 & \\
\hline Courses for capacitation offered by the input suppliers & & & 0.765 & \\
\hline Ex-post negotiation & 0.926 & & & \\
\hline Definition of the price paid for milk & 0.918 & & & \\
\hline Customer requirements & 0.915 & & & \\
\hline Know what is evaluated in milk & & & & 0.511 \\
\hline Data information regarding the activity & & & & 0.711 \\
\hline Compliance with the Brazilian requirements & & & & 0.710 \\
\hline
\end{tabular}

$\mathrm{SCC}=$ somatic cell count $\mathrm{TBC}=$ total bacteria count. Coefficients lower than 0.50 were deleted

Ciência Rural, v.45, n.11, nov, 2015. 
Exploratory factor analysis (EFA) resulted in four factors (Table 1). The cumulative total variance explained, using the four factors, was $74.74 \%$, thereby satisfying the minimum criteria established for the main component analysis (BARROSO \& ARTES, 2003). The analysis resulted in KMO value of 0.742 and Bartlett's test of 0.00 , indicating that the variables used are suitable for exploratory factor analysis statistics (HAIR et al., 1998; FÁVERO et. al., 2009).

Factor 1 (F1) was formed by variables related to information between dairy farmers and industry (transaction information), namely ex-post negotiation, information about the criteria for establishing prices and buyer's requirements (Table 1). Asymmetry Information can occur in these transactions, due to criteria to define milk price, such as (a) chemical composition and microbiological quality of milk, which are not usually measured by farmers; (b) the distance between farm and processing unit (freight cost) and (c) the milk volume. Thus, F1 becomes important as it decreases asymmetry information on transaction characteristics, lessening the possibility of opportunism and, consequently, lowering the risk for dairy farmers, as stated by ZYLBERSZTAJN (1995; 2009). In such situations, lower transaction costs can improve competitiveness for the system (FERNANDEZ-STARK et al., 2012).

Considering the price of milk in transactions between dairy farmers and industries, it is important to mention that it is not merely a function of product supply and demand, but rather related to the bargaining power of agents in transaction, resulted from social structures established in rural production (MAGALHÃES, 2007). FERNANDEZSTARK et al. (2012) consider the bargaining power of low and medium-income farmers to be increased when farmers have greater information access, either arising directly from the relationship with the buyer or obtained from the network among farmers.

Factor 2 (product characteristics information) was formed by variables concerning information about characteristics of milk and the ability to interpret them by dairy farmers on milk quality parameters, namely information about somatic cell counts (SCC), total bacteria counts (TBC), crude protein and fat in milk (Table 1). Knowledge on milk quality characteristics allows dairy farmers to have arguments about the value that they will receive. Thus, the lower the information asymmetry related to the characteristics of the negotiated product, the lower the possibility of opportunism by industry, as stated by FERNANDEZ-STARK et al. (2012). In addition, dairy farmers that produce better quality milk have more bargaining power, given the interest of dairy industries in this kind of milk. According to DÜRR (2006), the industry has more information regarding the importance of quality, both in relation to the consumer and to the milk producer. Thus, vertical transfer of information is an important factor. Variables related to farmers' technical and productive knowledge, specifically concerning access to technical assistance and training courses, formed Factor 3 (F3), which is called technical and productive information (Table 1). Better knowledge about these aspects can help to define better strategies for growth and adaptation of production compared to market demands (milk industry) and also legal changes, thus making the activity more competitive in medium and long term. This factor may be related to the development and remuneration of activity, since the higher the training of dairy farmers on the productive activity the higher the gains on quality, productivity, and food security (NEVES et al., 2002). Also, BÁNKUTI et al. (2009) consider the lack of technical and productive information of dairy farmers a major obstacle to market access.

FERNANDEZ-STARK et al. (2012) consider the qualification and training of dairy farmers in productive activities to generate an increased competitiveness due to the: (a) increased productivity, (b) improved product quality, (c) greater suitability of the product and production process by institutional characteristics (laws), and market (d) generation of scale economy and, (e) development of entrepreneurial skills. According to DÜRR (2006), higher levels of information of the dairy farmers can improve the milk quality, and thus, it may be better paid, increasing the profitability of production.

Finally, Factor 4 (F4) was determined by variables related to the search for general information on dairy production, market, economy, new products, production techniques, and technologies, comprising access to general information about dairy sector, information on aspects evaluated in milk and compliance with Brazilian sanitary and productive requirements (Table 1). Those were identified by initiatives of dairy farmers through ordinary communication channels, including magazines, newspapers, television, internet, and others. This factor was named general market information. The access to general information and the possibility of joining them to the characteristics of local production and market can result in better decisions, and therefore have a lower risk activity for dairy farmers. In addition, BUAINAIN et al. (2003) pointed out that deficient information may 
generate institutional problems regarding the access to basic inputs and efficient markets.

It was used as the independent variable "the participation in HA"; comparing the group that participated (67 dairy farmers) to those who did not participate (53 dairy farmers) for the four factors generated. According to data presented in table 2, the two groups were not different $(\mathrm{P}>0.05)$ for factor 2: product characteristics information, and factor 3: technical and productive information. This result indicates that the participation of dairy farmers in HA did not influence the access to information on these aspects. Thus, participating in HA haven't allowed dairy farmers more access to information on product characteristics or more access to technical assistance and training courses.

Regarding factor 2, after the initiative of payment for milk quality, dairy farmers have tended to seek information about the quality of their product. According to PAIVA et al. (2012), the implementation of a payment system for quality involves the exchange of information between dairy farmers and industry; and this is an important aspect to increase the competitiveness in DAS. CARVALHO \& BARCELLOS (2013) also highlight the importance of information exchange between industry and dairy farmers because industries have further information related to market demand. In addition, a product with better quality results in better performance and institutional adaptation for industry, considering sanitary conditions, for example. In this sense, Brazilian institutional environment, through the Normative Instruction 62/2011-MAPA, establishes technical and productive standards, as well as regulation, identity and quality patterns for raw and pasteurized milk (BRASIL, 2011). More detailed patterns for raw milk and the dissemination of the national milk quality program in Brazil may have directed processors' and farmers' attention to variables such as TBC and SCC, making farmers more informed about milk characteristics.

For Factor 3 (technical and productive information), similar $(\mathrm{P}>0.05)$ values were observed between the two groups analyzed. This result can be explained by the easier access to such information in recent years. In Paraná State, organizational environment is favorable, since there is a wide availability of technical and productive information easily accessible by farmers, such as those offered by the national rural educational service - SENAR and Paraná institute of technical assistance and rural extension - EMATER.

According to data presented in table 2, there is a significant difference $(\mathrm{P}<0.05)$ between means for Factor 1 (transaction information). Thus, farmers engaged in HA are more informed about transaction, being less subject to buyers' opportunistic behavior in these transactions and less subject to risks in milk activity. Opportunistic behavior by industry is also evidenced by BÁNKUTI et al. (2010) and CARVALHO \& BARCELLOS (2013), noting that in Brazil, information asymmetry between dairy farmers and the industry is high and reflects considerably in opportunistic behavior. Since the criteria for setting price may not be clear, the price can be set by the buyer ex-post the delivery of product.

Finally, significant differences $(\mathrm{P}<0.05)$ between the groups analyzed for Factor 4 (general market information) were observed. Dairy farmers who participate in HA have greater access to general information related to dairy activity, compared to those who do not participate in HA. According to RATINGER \& BOŠKOVÁ(2013) andFERNANDEZSTARK et al. (2012), information regarding the market price evolution influences managerial decisions taken by farmers. According to DÜRR (2006), the vision and general information about issues that impact the productive activity allow the generation of greater value access to the product being marketed.

According to RATINGER \& BOŠKOVÁ (2013), the lack of information regarding transactions is due to the bargaining and concentration power of the food industry against farmers. For these authors, this is a major incentive for formatting HA in rural production, which among others, may bring economic benefits and greater access to market information and to transactions, which was supported in this research.

Table 2 - Means for the factors regarding the information asymmetry of the dairy farmers who participate in horizontal arrangements (HA) and dairy farmers who do not participate.

\begin{tabular}{|c|c|c|c|c|c|}
\hline \multirow{2}{*}{ Participation in HA } & \multirow[b]{2}{*}{$\mathrm{n}$} & \multirow[b]{2}{*}{1} & \multirow[t]{2}{*}{-Factors } & \multirow[b]{2}{*}{3} & \multirow[b]{2}{*}{4} \\
\hline & & & & & \\
\hline Yes & 67 & $0.1694^{\mathrm{a}}$ & $-0.1011^{\mathrm{a}}$ & $-0.0986^{\mathrm{a}}$ & $0.1959^{\mathrm{a}}$ \\
\hline No & 53 & $-0.2141^{b}$ & $0.1278^{\mathrm{a}}$ & $0.1246^{\mathrm{a}}$ & $-0.2477^{b}$ \\
\hline
\end{tabular}

$\mathrm{n}=$ number of dairy farmers that belong in each group. Means in columns followed by different letters differed (P<0.05) using $\mathrm{t}$-student test. 
Results showed that dairy farmers who participate in HA have greater access to information concerning the characteristics of general market information and transaction information, compared to dairy farmers who do not participate in these arrangements. This result can be explained by the increased bargaining power of farmers and the increased flow of information that can occur between dairy farmers regarding general market information. For the latter, it may be mainly due meetings and group discussions promoted by HA representatives.

The similarity between the groups for product characteristics information indicated that farmers in general may reach information about product characteristics, either due to the industry initiative, institutional environment conditions or price incentives. Equality regarding technical and productive information and assistance may be due to the easier access to training and technical assistance in the state.

Although one may not state there is no information asymmetry between farmers in HA and industry, it is possible to state that participating in HA may decrease such asymmetry, giving farmers better transactional conditions. Findings in this research lend support to some statements on literature, such as those by FERNANDEZ-STARK et al (2012), CARVALHO \& BARCELLOS (2013), CARVALHO \& RIOS (2007) and RATINGER \& BOŠKOVÁ (2013).

\section{CONCLUSION}

Access to information is treated in the literature as an important aspect for the performance of dairy farmers and competitiveness of dairy systems as a whole. In this paper, that subject was considered for analyzing information asymmetry in transactions between farmers and buyers in DAS in Paraná state, Brazil, supported by the approach of NIE and TCE.

Results indicate differences in access to information by farmers participating in HA and those not engaged in such arrangements. More specifically, participating in HA seems not to be important for dairy farmers to access more objective information, such as those related to measured aspects of milk and technical assistance and training. Possibly, institutional and organizational environments may give support to farmers in this sense. On the other hand, HA, according to this research, can help dairy farmers to increase information about transaction (negotiation, definition of criteria and buyers' requirements), comprising variables related to bargaining power. Also, farmers in such arrangements seems to be more informed about market and institutional aspects, which may give support to make decisions and decrease risks in transactions. Participation in HA by dairy farmers seems to be an important strategy for reducing the risk, thus lending support to this research hypothesis. It indicates the importance of HA among farmers, which may help to reduce inefficiencies in dairy system. Moreover, this research highlights the viability of analyzing information asymmetry through methodological procedures proposed. Nevertheless, other variables could be included in future studies. Also, deeper theoretical considerations regarding NIE and TCE, as well as other approaches on information asymmetry (e.g. Principal-Agent Theory) could bring relevant contributions to the analysis of agri-food systems. Finally, studies on vertical arrangements would be useful to help understand access to information by farmers and asymmetry information in transactions.

\section{ACKNOWLEDGEMENTS}

PLEXSUS - Research Program of Dairy Systems, Extension and Sustainable Production, process 562981/2010-1; to REPENSA - Conselho Nacional de Desenvolvimento Científico e Tecnológico (CNPq) e Fundação Araucária (FA).

\section{REFERENCES}

BÁNKUTI, F.I. et al. Entraves para inserção de produtores de leite no mercado formal da Região de São Carlos, Estado de São Paulo. Informações Econômicas, v.39, p.19-31, 2009. Available from: $<$ http://www.iea.sp.gov.br/out/LerTexto.php?codTexto=11538>. Accessed: Nov. 18, 2009.

BÁNKUTI, S.M.S. et al. Sistema agroindustrial do leite: um estudo das estruturas de governança a partir de experiências no Brasil e na França. Informações Econômicas, v.40, p.45-56, 2010. Available from: <http://www.iea.sp.gov.br/out/LerTexto. php?codTexto=12022>. Accessed: Apr. 03, 2012.

BARROSO, L.P. ARTES R. Análise multivariada. Lavras: UFLA, 2003. 151p.

BAUM, J.A.C.; INGRAM, P. Interorganizational learning and network organization: toward a behavioral theory of the interfirm. In: AUGIER, M.; MARCH, J.G. (Ed.). The economics of change, choice and structure. Cheltenham, United Kingdom: Edward Elgar, 2002. p.191-218.

BRASIL. MINISTÉRIO DA AGRICULTURA PECUÁRIA E ABASTECIMENTO (MAPA). Instrução Normativa n.62. Brasil, 2011. Available from: <http://sistemasweb.agricultura.gov.br/ sislegis $>$. Accessed: Ago. 22, 2013.

BUAINAIN, A.M. et al. Agricultura familiar e o novo mundo rural. Sociologias, v.5, p.312-347, 2003. Available from: $<$ http://www.scielo. br/scielo.php?script=sci_arttext\&pid=S1517-45222003000200011>. Accessed: Jun. 17, 2008. doi: 10.1590/S1517-45222003000200011.

CARVALHO, D.M.; BARCELLOS, J.O.J. Orientação para o mercado no elo da produção de leite: como lidar com a assimetria 
de informação. Organizações Rurais \& Agroindustriais, v.15, p.155-166, 2013. Available from: <http://www.spell.org.br/ documentos/download/14403>. Accessed: Mar. 28, 2010.

CARVALHO, D.M.; RIOS, G.S.L. Participação, viabilidade e sustentabilidade: dimensões de desenvolvimento local numa associação de produtores rurais. Organizações Rurais \& Agroindustriais, v.9, p.402-420, 2007. Available from: <http://www. redalyc.org/articulo.oa?id=87890308>. Accessed: Ago. 22, 2010 .

DÜRR, J.W. Controle de qualidade e aumento da competitividade da indústria láctea. In: MARTINS. C.E. (Ed.). Tendências e avanços do agronegócio do leite nas Américas: Industrialização. Juiz de Fora: Embrapa Gado de Leite, 2006. p.81-94. Available from: <http://www.fepale.org/sitio_viejo/lechesalud/ documentos/7JoaoDurr.pdf $>$. Accessed: Feb. 15, 2012.

FÁVERO, L.P. et al. Análise de dados: modelagem multivariada para tomada de decisões. Rio de Janeiro: Elsevier, 2009. 646p.

FERNANDEZ-STARK, K. et al. Inclusion of small and mediumsized producers in high value agrofood value chains. Duke Center on Globalization, Governance and Competitiveness, 2012. Available from: <http://www.cggc.duke.edu/pdfs/CGGCIDB_\%20Inclusion_of_Small-_and_Medium-Sized_Producers in_High-Value_Agro-Food_Value_Chains_May_1_2012.pdf $>$. Accessed: Mar. 31, 2013.

HAIR, J.F. et al. Multivariate data analysis. New Jersey: Prentice Hall, 1998. 757p.

IBGE (INSTITUTO BRASILEIRO DE GEOGRAFIA E ESTATÍSTICA). Pesquisa da pecuária municipal. IBGE, 2014. Available from: <http://sibra.ibge.gov.br>. Accessed: Jul. 20, 2014.

IBGE (INSTITUTO BRASILEIRO DE GEOGRAFIA E ESTATÍSTICA). Censo Agropecuário. IBGE, 2006. Available from: <http://sidra.ibge.gov.br>. Accessed: Ago. 04, 2010.

JANK, M.S. et al. O agribusiness do leite no Brasil. São Paulo: Milkbizz, 1999. 108p.

LEBART, L. Contiguity analysis and classification. In: GAUL, W. et al. (Eds.). Data analysis. Berlin: Springer, 2000. p.233-244.

MAGALHÃES, R.S. Habilidades sociais no mercado de leite. Revista de Administração de Empresas, v.47, p.1-11, 2007. Available from: <http://www.scielo.br/scielo.php?pid=S003475902007000200003\&script $=$ sci_arttext $>$. Accessed: Oct. 28, 2013. doi: $10.1590 / \mathrm{S} 0034-75902007000200003$.

NEVES, M.F. et al. Marketing e ações coletivas em redes de empresas: o caso da carne bovina no Mato Grosso do Sul. In: CONGRESSO DA SOCIEDADE BRASILEIRA DE
ADMINISTRAÇÃO, ECONOMIA E SOCIOLOGIA RURAL, SOBER, 40., 2002, Passo Fundo, RS. Anais... Passo Fundo, RS: UPF, 2002. p.181

NOGUEIRA, A.C.L. Custos de transação e arranjos institucionais alternativos: uma análise da avicultura de corte no estado de São Paulo. 2003. 153f. Dissertação (Mestrado em Administração) - Faculdade de Economia, Administração e Contabilidade. Universidade de São Paulo, SP.

NORTH, D.C. Institutions, institucional change and economic performance. Cambridge: Cambridge University, 1990. 159p.

PAIVA, C.A.V. et al. Evolução anual da qualidade do leite cru refrigerado processado em uma indústria de Minas Gerais. Arquivo Brasileiro de Medicina Veterinária e Zootecnia, v.64, p.471-479, 2012. Available from: $<$ http://www.scielo.br/scielo.php?script $=$ sci arttext\&pid=S0102-09352012000200030 $>$. Accessed: May 21, 2014. doi: 10.1590/S0102-09352012000200030.

RATINGER, T.; BOŠKOVÁ, I. Strategies and effects of milk producers' organizations in the Czech Republic. Agricultural Economics, v.59, p.113-124, 2013. Available from: <http://www.agriculturejournals.cz/ publicFiles/88575.pdf $>$. Accessed: Jul. 11, 2014.

SMITH, R.R. et al. Caracterización de sistemas productivos lecheros en la $\mathrm{X}$ región de Chile mediante análisis multivariable. Agricultura técnica, v.62, p.375-395, 2002. Available from: $<\mathrm{http}: / /$ www.scielo. cl/scielo.php?pid=S0365-28072002000300004\&script=sci_arttext $>$. Accessed: Jul. 07, 2012. doi: 10.4067/S0365-28072002000300004.

STIGLITZ, J.E. Information and the change in the paradigm in economics. American Economic Review, v.92, n.3, p.460-501, 2002. Available from: <https://www.aeaweb.org/articles.php?d oi $=10.1257 / 00028280260136363>$. Accessed: Ago. 13, 2011. doi: $10.1257 / 00028280260136363$.

USDA (UNITED STATES DEPARTMENT OF AGRICULTURE). Market and trade data. Online. Available from: <http://apps.fas. usda.gov/psdonline/psdquery.aspx>. Accessed: Sept. 28, 2014.

WILLIAMSON, O.E. The economic institutions of capitalism firms, markets, relational contracting. New York: The Free, 1985. 468p.

ZYLBERSZTAJN, D. Estruturas de governança e coordenação do agribusiness: uma aplicação da nova economia das instituições. 1995. 241f Tese (Livre Docência) - Departamento de Administração. Faculdade de Economia, Administração e Contabilidade. Universidade de São Paulo, SP.

ZYLBERSZTAJN, D. From contracts to networks: new directions in the study of governance of agro-food-energy networks. International European Forum on Systems Dynamics and Innovation in Food Networks, v.1, Feb, p.1-27, 2009. 